\title{
Influence of low-opioid anesthesia in cardiac surgery on dynamics of pro-inflammatory interleukin-6
}

\author{
Oleh Loskutov ${ }^{1}$, Stepan Maruniak ${ }^{1}$, Olexandr Dryzhyna ${ }^{2}$, Ihor Malysh ${ }^{3}$, Volodymyr Kolesnykov ${ }^{1}$, \\ Natalia Korotchuk ${ }^{2}$ \\ ${ }^{1}$ Shupyk National Medical Academy of Postgraduate Education, Kyiv, Ukraine \\ ${ }^{2}$ State Institution "Heart Institute Ministry of Health of Ukraine", Kyiv, Ukraine \\ ${ }^{3}$ Clinical Municipal Communal Emergency Hospital, Kyiv, Ukraine
}

Kardiochir Torakochir Pol 2020; 17 (1): 39-43

\begin{abstract}
Introduction: With coronary artery bypass grafting, patients are subjected to additional risk caused by both surgical treatment itself and pathophysiological changes in homeostasis, provoked by the action of anesthetics and cardiopulmonary bypass.

Material and methods: The study involved 60 patients, who had been subjected to coronary artery bypass grafting with cardiopulmonary bypass. All patients were divided into two groups: group I (30 patients) - low-opioid scheme of anesthesia and group II (30 patients) - standard scheme of anesthetic management. Blood interleukin-6 (IL-6) was identified before and after cardiopulmonary bypass using an ELISA test.

Results: Having compared IL-6 values between study groups after completion of cardiopulmonary bypass, it was established that IL-6 levels were $27.51 \%(p=0.001)$ lower in patients of group I compared with the results of patients in group II. Patients in the first group had a significantly shorter time of mechanical ventilation compared to group II (2.1 \pm 0.7 hours vs. $3.9 \pm 0.9$ hours, $p=0.021$ ). Low cardiac output syndrome was significantly less frequently reported in patients of group I (10.0\% vs. $33.3 \%, p=0.028)$. In addition, patients in group I had a significantly shorter time of intensive care unit (ICU) stay ( $2.5 \pm 0.7$ days vs. $3.5 \pm 1.0$ days, $p=0.044$ ).

Conclusions: Application of multimodal low-opioid anesthesia was associated with significantly lower IL- 6 at the end of surgery, shorter mechanical ventilation duration, less frequent low cardiac output syndrome and need for catecholamines, and shorter ICU stays.
\end{abstract}

Key words: coronary heart disease, coronary artery bypass grafting, cardiopulmonary bypass, interleukin-6.

\section{Streszczenie}

Wprowadzenie: Oprócz ryzyka związanego z samą operacją, pacjenci poddawani pomostowaniu aortalno-wieńcowemu są także narażeni na dodatkowe ryzyko wywoływane przez patofizjologiczne zmiany homeostazy wskutek działania środków anestetycznych i stosowania krążenia pozaustrojowego.

Materiał i metody: Badaniem objęto 60 pacjentów, u których wykonano pomostowanie aortalno-wieńcowe z zastosowaniem krążenia pozaustrojowego. Pacjentów podzielono na dwie grupy: grupa I (30 pacjentów) - schemat znieczulenia niskoopioidowego oraz grupa II (30 pacjentów) - standardowy schemat postępowania anestezjologicznego. Stężenie interleukiny 6 (IL-6) we krwi oznaczano za pomocą testu ELISA przed zastosowaniem krążenia pozaustrojowego i po jego zastosowaniu.

Wyniki: Porównanie stężeń IL-6 pomiędzy badanymi grupami po zakończeniu krążenia pozaustrojowego wykazało, że wartości IL-6 były mniejsze o 27,51\% ( $p=0,001)$ u pacjentów z grupy I w porównaniu z pacjentami z grupy II. U chorych z grupy I czas wentylacji mechanicznej był istotnie krótszy niż u pacjentów z grupy $\|(2,1 \pm 0,7$ godziny vs $3,9 \pm 0,9$ godziny, $p=0,021)$. Zespół niskiego rzutu serca był zgłaszany istotnie rzadziej u chorych z grupy I $(10,0 \%$ vs $33,3 \%, p=0,028)$. Ponadto czas pobytu na oddziale intensywnej terapii $u$ chorych z grupy I byt istotnie krótszy $(2,5 \pm 0,7$ doby vs $3,5 \pm 1,0$ doba, $p=0,044)$.

Wnioski: Zastosowanie wielomodalnego znieczulenia niskoopioidowego wiązało się z istotnie niższym stężeniem IL-6 po operacji, krótszym czasem wentylacji mechanicznej, rzadszym występowaniem zespołu niskiego rzutu serca i potrzebą stosowania katecholamin oraz krótszym pobytem na oddziale intensywnej terapii.

Słowa kluczowe: choroba wieńcowa, pomostowanie aortalno-wieńcowe, krążenie pozaustrojowe, interleukina 6.

Address for correspondence: Dr. Stepan Maruniak, Shupyk National Medical Academy of Postgraduate Education, Henerala Vatutina 30,107, 20017 Kyiv, Ukraine, phone: +38 0509510268, e-mail: maruniak.stepan@gmail.com Received: 10.10.2019, accepted: 20.01.2020. 


\section{Introduction}

Currently, coronary heart disease (CHD) holds the leading position among all causes of mortality [1]. Coronary artery bypass grafting (CABG) is considered the most effective and long-lasting method of CHD treatment due to positive postponed results [2]. However, during surgical intervention, patients are subjected to additional risk, which is caused by the surgery itself as well as pathophysiological changes in homeostasis, caused by the action of anesthetics and cardiopulmonary bypass [3].

Thus, according to modern studies, cardiac procedures with involvement of cardiopulmonary bypass (CPB) are able to provoke the development of systemic inflammatory response syndrome (SIRS) [4]. Contact of blood components with the foreign surface of the extracorporeal contour, ischemia-reperfusion injuries, endotoxemia and surgical trauma are among the processes which can cause SIRS development during surgery [5]. In turn, the development of an excessive inflammatory response triggers a cascade of apoptotic reactions in the internal organs and blood cells [6]. Consequently, different post-surgical complications may develop, such as myocardial dysfunction, respiratory failure, neurological and renal dysfunction, impairment of blood clotting, disturbance of liver function and even multiple organ failure, etc. [7].

Production of pro-inflammatory cytokines, in particular interleukin-6 (IL-6), is an important component in pathogenesis of CPB-associated complications [8]. IL-6 is considered an important biomarker of cardiac activity condition and myocardial damage, as well as one of the inflammatory markers of coronary plaque, and in high concentrations it is detected in fatty streaks of atherosclerotic plaque [9, 10]. Moreover, according to data of some studies, high plasma concentration of IL- 6 in patients with acute coronary syndrome is associated with the risk of serious coronary events [11].

\section{Aim}

The aim of our research was to assess the influence of a low-dose opioid scheme of anesthetic management on dynamics of cytokines (IL-6) in CABG with CPB.

\section{Material and methods \\ Study population}

The study involved 60 patients with coronary heart disease, who had undergone coronary artery bypass grafting with cardiopulmonary bypass in State Institution "Heart Institute Ministry of Health of Ukraine". The mean age of patients was $60.6 \pm 4.1$ years (from 48 to 65 years). Mean body weight $-90.5 \pm 13.8 \mathrm{~kg}$ (from 73 to $125 \mathrm{~kg}$ ). The number of males was 40 (66.7\%), females - 20 (33.3\%). The mean EuroSCORE II value was $3.6 \pm 0.8 \%$.

\section{Exclusion criteria}

- Emergency surgery.

- Redo surgery.
- Patients with the left internal mammary artery - left anterior descending coronary artery bypass graft.

- Patients with 1 aorto-coronary anastomosis and patients with 4 or more aorto-coronary anastomoses.

- EuroSCORE II more than 5\%.

\section{Randomization}

According to the scheme of anesthetic management, all patients were divided into two groups. We used computergenerated lists for randomization.

\section{Characteristics of groups}

Group I (30 patients) - induction implied intravenous injection of propofol at the dose of $1.5-2.0 \mathrm{mg} / \mathrm{kg}, 40 \mathrm{mg}$ with an interval of 10-15 seconds. After introduction of hypnotics, all patients received $1.5 \mu \mathrm{g} / \mathrm{kg}$ of fentanyl intravenously. After achieving an adequate level of anesthesia, muscle relaxation was achieved by intravenous injection of pipecuronium bromide at the dose of $0.1 \mathrm{mg} / \mathrm{kg}$ followed by intubation of the trachea. To maintain anesthesia, inhalation of sevoflurane was applied via a semi-closed contour with targeted maintenance of its concentration according to the age index of minimum alveolar concentration (MAC). Targeted concentration of sevoflurane was calculated by the formula: MAC-awake $=0.34 \times$ MACtabl $\times 2$. Before the onset of surgical intervention, a sub-narcotic dose of ketamine $(0.5 \mathrm{mg} / \mathrm{kg})$ was added intravenously and $1 \mathrm{mg} / \mathrm{kg}$ of lidocaine in bolus injection, with simultaneous continuous infusion of the latter at the dose of $1.5-2 \mathrm{mg} / \mathrm{kg} / \mathrm{hour}$ and dexmedetomidine $0.7 \mu \mathrm{g} / \mathrm{kg} / \mathrm{hour}$. Infusion of lidocaine was maintained throughout the entire operation until admission of the patient to the intensive care ward. Maintenance of analgesia during surgery was performed with fentanyl injection, if necessary.

The second group (30 patients) - standard scheme of anesthetic management (induction into anesthesia - similar to that in patients of the first group); maintenance of anesthesia - sevoflurane 1.5-2 MAC, standard doses of fentanyl $20-25 \mu \mathrm{g} / \mathrm{kg}$ during entire operation, pipecuronium bromide - at the dose of $0.1 \mathrm{mg} / \mathrm{kg}$.

Characteristics of these groups are presented in Table I.

\section{Perioperative procedure}

Mechanical ventilation (MV) in examined patients was performed using an oxygen/air mixture with $\mathrm{FiO}_{2}, 50 \%$ in the regimen of normal ventilation controlling gas composition of blood.

CPB was conducted using a System 1 device (Terumo, USA) with Affinity disposable membranous oxygenators (Medtronic, USA) under conditions of moderate hypothermia $\left(+32^{\circ} \mathrm{C}\right)$.

Connection of CPB machine and perfusion during artificial electrical cardiac fibrillation was performed in nonpulsatile mode with further transition to pulsatile mode of CPB (cardiac index was maintained at the level of 2.4-2.5 $\mathrm{l} / \mathrm{min} / \mathrm{m}^{2}$ ). During CPB, normovolemic hemodilution was used with the level of hematocrit $25-30 \%$ and 
hemoglobin 80-90 g/l. Blood clotting was assessed by the activated clotting time (ACT), maintaining it within 480600 seconds.

The endpoints analyzed in this study included low cardiac output syndrome (LCOS). LCOS includes decreases in the cardiac index $(\mathrm{Cl})$ to $<2.0 \mathrm{l} / \mathrm{min} / \mathrm{m}^{2}$ and a systolic blood pressure of $<90 \mathrm{~mm} \mathrm{Hg}$, in conjunction with signs of tissue hypoperfusion (cold periphery, clammy skin, confusion, oliguria, elevated lactate level) in the absence of hypovolemia.

\section{Determination of IL-6}

Determination of blood IL-6 level was performed before and after completion of CPB using the ELISA method with a set by Immunotech (a Coulter company, France).

The study was conducted in accordance with the seventh revision of the principles of the Declaration of Helsinki on Human Rights (2013). Informed consent was obtained from the patients.

\section{Statistical analysis}

The obtained results were statistically assessed using Student's $t$-test. The data are presented as the arithmetic mean $(M)$ based on the results of each study \pm standard deviation (SD). If the results showed a skewed distribution, comparisons were performed using the Mann-Whitney $U$. The differences at $p<0.05$ (95.5\%) were considered significant. Analysis of the obtained results was performed using the computer program XLSTAT.

\section{Results}

Mean dose of fentanyl used throughout the entire period of anesthetic management for patients of group I constituted $1.09 \pm 0.03 \mu \mathrm{g} / \mathrm{kg} /$ hour. As to the patients of group II, the total dose of fentanyl during surgery was $21.5 \pm 3.4 \mu \mathrm{g} / \mathrm{kg}$, which was 19.7 times significantly higher $(p=0.007)$ than in group I.

Numbers of anastomoses, total duration of operation and anesthesia, as well as duration of CPB and aortic crossclamping, did not differ significantly between study groups $(p>0.05)$ (Table II).

Concerning determination of IL- 6 level before the start of $\mathrm{CPB}$, there was no difference in primary values of IL- 6 between study groups ( $p=0.395)$ (Table III).

The low-dose opioid scheme of anesthetic management was characterized by a significant increase in IL- 6 level by 5.26 times $(p<0.0001)$ compared with primary data (Table III). A standard scheme of anesthetic management was also accompanied by significant elevation of IL-6 levels by 6.88 times $(p<0.0001)$ compared with primary values (Table III).

Meanwhile, having compared IL-6 values after cessation of CPB between study groups, it was established that in the patients of group I IL-6 levels were significantly lower by $27.51 \%(p=0.001)$ compared with those in patients of group II (Table III).

Patients in group I had a significantly shorter time of mechanical ventilation compared to group II (2.1 \pm 0.7 hours vs.
Table I. Characteristics of patient study groups

\begin{tabular}{lccc} 
Index & $\begin{array}{c}\text { Group I } \\
(n=30)\end{array}$ & $\begin{array}{c}\text { Group II } \\
(n=30)\end{array}$ & $\begin{array}{c}P \text {-value, } \\
\alpha=0.05\end{array}$ \\
Female sex, $n(\%)$ & $9(30.00)$ & $11(26.67)$ & 0.421 \\
\hline Age, mean \pm SD [years] & $59.8 \pm 4.9$ & $60.3 \pm 4.2$ & 0.851 \\
\hline Body weight, mean \pm SD $[\mathrm{kg}]$ & $92.1 \pm 22.2$ & $88.7 \pm 20.1$ & 0.505 \\
\hline $\begin{array}{l}\text { Myocardial infarction } \\
\text { in anamnesis, } n(\%)\end{array}$ & $8(25.67)$ & $7(23.33)$ & 0.205 \\
\hline Diabetes type II, $n(\%)$ & $3(10.0)$ & $2(6.7)$ & 0.381 \\
\hline PCI in anamnesis, $n(\%)$ & $4(13.3)$ & $7(23.3)$ & 0.141 \\
\hline Arterial hypertension, $n(\%)$ & $21(70.0)$ & $23(76.7)$ & 0.506 \\
\hline Stroke in anamnesis, $n(\%)$ & $1(3.3)$ & $1(3.3)$ & 1.0 \\
\hline EuroSCORE II, mean \pm SD \% & $3.5 \pm 0.6$ & $3.6 \pm 0.9$ & 0.193 \\
\hline Functional class NYHA, $n(\%):$ & \multicolumn{3}{l}{} \\
\hline II & $13(43.33)$ & $11(36.67)$ & 0.417 \\
\hline III & $17(56.67)$ & $19(63.33)$ & \\
\hline LVEF, mean \pm SD \% & $46.5 \pm 8.1$ & $47.2 \pm 9.6$ & 0.681 \\
\hline LVEF $<30,0 \%, n(\%)$ & $6(20.0)$ & $8(26.7)$ & 0.461 \\
\hline Creatinine, \\
mean \pm SD [mmol/I] & $96.5 \pm 11.4$ & $89.8 \pm 16.3$ & 0.09 \\
\hline
\end{tabular}

Table II. Comparison of perioperative results between study groups

$\begin{array}{llll}\text { Parameter } & \begin{array}{l}\text { Group I } \\ (n=30)\end{array} & \begin{array}{l}\text { Group II } \\ (n=30)\end{array} & \begin{array}{c}\text { P-value, } \\ \alpha=0.05\end{array}\end{array}$

Numbers of anastomoses,

$n(\%)$ :

\begin{tabular}{lccc}
\hline 2 & $12(40.0)$ & $9(30.0)$ & 0.316 \\
\hline 3 & $18(60.0)$ & $21(70.0)$ & \\
\hline Duration of surgery [min] & $207.4 \pm 19.2$ & $214.1 \pm 23.2$ & 0.211 \\
\hline Duration of anesthesia [min] & $228.3 \pm 25.1$ & $231.4 \pm 31.2$ & 0.180 \\
\hline Duration of CPB [min] & $82.3 \pm 11.7$ & $83.9 \pm 13.3$ & 0.591 \\
\hline $\begin{array}{l}\text { Duration of aortic } \\
\text { cross-clamping [min] }\end{array}$ & $24.4 \pm 5.9$ & $25.3 \pm 5.1$ & 0.570 \\
\hline
\end{tabular}

CPB - cardiopulmonary bypass.

Table III. Dynamics of changes in IL- 6 levels due to CABG with CPB depending on the scheme of anesthetic management

\begin{tabular}{lccc} 
Groups/period & $\begin{array}{c}\text { Group I } \\
(n=30)\end{array}$ & $\begin{array}{c}\text { Group II } \\
(n=30)\end{array}$ & $\begin{array}{c}P \text {-value, } \\
\alpha=0.05\end{array}$ \\
\hline Before CPB [pg/ml] & $6.1 \pm 1.4$ & $6.4 \pm 1.3$ & $0.395^{\wedge}$ \\
\hline After CPB [pg/ml] & $32.2 \pm 8.4$ & $44.5 \pm 16.6$ & $<0.0001^{\wedge}$ \\
\hline$P$-value, $\alpha=0.05$ & $<0.0001^{\star}$ & $<0.0001^{\star}$ & \\
\hline
\end{tabular}

CPB - cardiopulmonary bypass; ^ ${ }^{\wedge}$ compared between IL- 6 value in groups; *compared between IL- 6 value before and after CPB.

$3.9 \pm 0.9$ hours, $p=0.021$ ) (Table IV). As to cardiac complications, the frequency of atrial fibrillation (10.0\% vs. $30.0 \%$, $p=0.052)$, ventricular tachycardia or fibrillation (3.3\% vs. $10.0 \%, p=0.304)$, and atrio-ventricular block (13.3\% vs. $6.7 \%$, $p=0.304$ ) did not differ significantly between study groups. At the same time, low cardiac output syndrome was significantly less frequently reported in patients of group I (10.0\% vs. $33.3 \%, p=0.028$ ). Accordingly, catecholamines were less 
Table IV. Post-operative characteristics of study groups

\begin{tabular}{|c|c|c|c|}
\hline Variables & $\begin{array}{l}\text { Group I } \\
(n=30)\end{array}$ & $\begin{array}{l}\text { Group II } \\
(n=30)\end{array}$ & $\begin{array}{l}P \text {-value, } \\
\alpha=0.05\end{array}$ \\
\hline $\begin{array}{l}\text { Postoperative ventilation } \\
\text { times [hours] }\end{array}$ & $2.1 \pm 0.7$ & $3.9 \pm 0.9$ & 0.021 \\
\hline Reintubation, $n(\%)$ & $2(6.7)$ & $5(16.7)$ & 0.227 \\
\hline \multicolumn{4}{|l|}{ Cardiac complication, $n$ (\%): } \\
\hline Atrial fibrillation & $3(10.0)$ & $9(30.0)$ & 0.052 \\
\hline $\begin{array}{l}\text { Ventricular tachycardia } \\
\text { or fibrillation }\end{array}$ & $1(3.3)$ & $3(10.0)$ & 0.304 \\
\hline Atrio-ventricular block & $4(13.3)$ & $2(6.7)$ & 0.389 \\
\hline $\begin{array}{l}\text { Low cardiac output } \\
\text { syndrome }\end{array}$ & $3(10.0)$ & $10(33.3)$ & 0.028 \\
\hline \multicolumn{4}{|c|}{ Catheholamine on first p/o day, $n(\%)$ : } \\
\hline Norepinephrine & $9(30.0)$ & $16(53.3)$ & 0.066 \\
\hline Dobutamine & $5(16.7)$ & $13(43.3)$ & 0.025 \\
\hline \multicolumn{4}{|l|}{ Lactate [mmol/l]: } \\
\hline At admission to ICU & $2.05 \pm 0.45$ & $2.28 \pm 0.56$ & 0.083 \\
\hline On first postoperative day & $1.87 \pm 0.27$ & $1.98 \pm 0.35$ & 0.337 \\
\hline \multicolumn{4}{|l|}{ Creatinine $[\mathrm{mmol} / \mathrm{l}]:$} \\
\hline At admission to ICU & $102.0 \pm 18.1$ & $100.5 \pm 10.7$ & 0.608 \\
\hline On first postoperative day & $90.5 \pm 11.4$ & $91.4 \pm 10.8$ & 0.743 \\
\hline ICU stay [day] & $2.5 \pm 0.7$ & $3.5 \pm 1.0$ & 0.044 \\
\hline Hospital stay [day] & $10.8 \pm 1.4$ & $11.6 \pm 1.8$ & 0.654 \\
\hline Hospital mortality, n (\%) & $0(0.0)$ & $1(3.3)$ & 0.879 \\
\hline
\end{tabular}

ICU - intensive care unit.

frequently used in patients in group I on the first postoperative day: norepinephrine $(16.7 \%$ vs. $43.3 \%, p=0.025)$ and dobutamine (30.0\% vs. $53.3 \%, p=0.066)$. Creatinine and lactate values did not differ on the first postoperative day. In addition, patients in group I spent a significantly shorter time in the ICU ( $2.5 \pm 0.7$ days vs. $3.5 \pm 1.0$ days, $p=0.044$ ), although hospitalization duration did not differ significantly between study groups.

\section{Discussion}

According to study results, the application of multimodal low-opioid anesthesia was associated with significantly lower IL- 6 at the end of surgery, shorter mechanical ventilation duration, less frequent low cardiac output syndrome and a need for catecholamines, and shorter ICU stays.

Recently, Rong et al. in an extensive meta-analysis, which involved 1400 patients, found that low-dose opioid anesthesia is safe and effective for use in adult patients for cardiosurgical interventions. Moreover, its efficacy does not depend on clinical characteristics of patients, type of opioid used and dose of opioids in groups with low-dose opioid anesthesia [12].

We chose the determination of IL- 6 level to assess the efficacy of a low-dose opioid scheme of anesthetic management, since its concentration in blood serum is a good indicator of the inflammation cascade activation and a predictor of further morbidity and mortality [9].
Thus, in our research, low-dose anesthesia management was characterized by a significant decrease in inflammatory response, namely, production of pro-inflammatory IL-6, which could be achieved by both direct reduction of fentanyl dose and addition of such medicines as lidocaine, ketamine or dexmedetomidine. Particularly, in the Luggya et al. study, administration of sub-narcotic doses of ketamine $(0.5 \mathrm{mg} / \mathrm{kg})$ in cardiosurgical interventions was characterized by a significantly lower level of IL- 6 in blood serum in the early post-operative period compared with a placebo group [13].

As for dexmedetomidine, based on the Li et al. metaanalysis the use of that agent during general anesthesia significantly decreased the levels of IL-6, IL-8 and tumor necrosis factor $\alpha$ (TNF- $\alpha$ ), whereas there was an increase in anti-inflammatory cytokines, such as IL-10 [14].

A similar effect on dynamics of interleukins was also reported for lidocaine. In particular, according to the de Oliveira et al. study, administration of lidocaine at the dose of $2 \mathrm{mg} / \mathrm{kg} /$ hour was characterized by a significant decrease in post-operative stress response, including a lower level of IL-6 as compared with placebo groups [15].

As reported by Yang et al. the increased production of IL-6 is associated with decreased myocardial contractility, which may be clinically manifested in low cardiac output syndrome in the postoperative period [16]. Indeed, in our study, when using low-opioid multimodal anesthesia, both the levels of IL- 6 and the incidence of low cardiac output syndrome were significantly lower compared to the standard anesthesia scheme. Accordingly, patients with a standard anesthesia scheme needed more catecholamine use on the first postoperative day.

In addition, atrial fibrillation and ventricular tachycardia or fibrillation were less frequent in patients with multimodal low-opioid anesthesia, although without a significant difference between the groups. First of all, it may be due to the antiarrhythmic properties of lidocaine, which blocks the sodium channels in the conduction system, as well as the muscle cells of the heart, and raises the depolarization threshold, making the heart less likely to initiate or conduct early action potentials [17]. On the other hand, this effect may also be due to the antiarrhythmic effect of dexmedetomidine - a highly selective $\alpha 2$ receptor agonist. By activating G-protein transmembrane $\alpha 2$ receptors in the brain, dexmedetomidine can theoretically affect the transmission of sympathetic activity from the central to the peripheral nervous system and elicit an antiarrhythmic effect [18]. Activation of the vagus nerve was also thought to be a mechanism responsible for the anti-arrhythmic effect of dexmedetomidine [19].

At the same time, AV block when using dexmedetomidine may also be more common due to activation of the vagus nerve. Thus, in our study, when using a multimodal anesthesia scheme, the AV block was observed more often, although with no significant difference between groups.

As reported by Duncan et al. in a recent meta-analysis, the use of dexmedetomidine provided good hemodynamic 
stability during surgery with less tachycardia and arterial hypertension, a positive effect on confusion and atrial fibrillation, with a shorter time to extubation and a shorter ICU length of stay [20].

In our study, patients with a low-opioid anesthesia scheme had a shorter duration of mechanical ventilation and stay in the ICU, which was consistent with the work of Guinot's et al., who used lidocaine, dexamethasone, and ketamine for the low-opioid anesthesia scheme [21].

As to ketamine, the main purpose of its use in the scheme of multimodal low-opioid anesthesia is potentiation of analgesics, which reduces the need for opioids [22].

Our study had several limitations. The relatively small number of patients in our population might limit our study's external validity. In addition, for the analysis of the inflammatory response, we evaluated only one indicator, IL-6, not the cytokine pro- and anti-inflammatory profile as a whole, which may not reflect all aspects of the inflammatory response.

\section{Conclusions}

Our study demonstrated that the multimodal low-opioid anesthesia with a combination of ketamine, lidocaine, and dexmedetomidine is characterized by relative safety, a lower inflammatory response, lower rates of cardiac complications and shorter duration of mechanical ventilation and stay in ICU. Further randomized studies with more patients are required to confirm these results.

\section{Disclosure}

The authors report no conflict of interest.

\section{References}

1. Handziuk VA. Analysis of ischemic heart disease morbidity in Ukraine. Ukrain Cardiol J 2014; 3: 45-52.

2. Mozaffarian D, Benjamin EJ, Go AS, Arnett DK, Blaha MJ, Cushman M, de Ferranti S, Després JP, Fullerton HJ, Howard VJ, Huffman MD, Judd SE, Kissela BM, Lackland DT, Lichtman JH, Lisabeth LD, Liu S, Mackey RH, Matchar DB, McGuire DK, Mohler ER 3rd, Moy CS, Muntner P, Mussolino ME, Nasir K, Neumar RW, Nichol G, Palaniappan L, Pandey DK, Reeves MJ, RodriguezCJ, SorliePD, SteinJ, TowfighiA, TuranTN, ViraniSS, WilleyJZ, Woo D, YehRW, Turner MB; American Heart Association Statistics Committee and Stroke Statistics Subcommittee. Heart disease and stroke statistics-2015 update: a report from the American Heart Association. Circulation 2015; 131: e29-e32.

3. Barbarash LS, Grigoriev EV, Plotnikov GP, Khaes BL, Moiseyenkov GV, Shukevich DL, Ivanov SV, Odarenko YN. Multiple organ failure after cardiosurgical interventions. General Reanimatol 2010; 6: 31-34.

4. Bronicki RA, Hall M. Cardiopulmonary bypass-induced inflammatory response: pathophysiology and treatment. Pediatr Crit Care Med 2016; 17: 272-278.
5. Corral-Velez V, Lopez-Delgado JC, Betancur-Zambrano NL, Lopez-Suńe N, Rojas-Lora M, Torrado H, Ballus J. The inflammatory response in cardiac surgery: an overview of the pathophysiology and clinical implications. Inflamm Allergy Drug Targets 2015; 13: 367-370.

6. Hernandez A, Shaw AD. Age and inflammation after cardiac surgery. Br J Anaesth 2017; 119: 562-563.

7. Butcher SK, Lord JM. Stress responses and innate immunity: aging as a contributory factor. Aging Cell 2004; 3: 151-160.

8. Rus H, Vlaicu R, Niculescu F. Interleukin- 6 and interleukin-8 protein and gene expression in human arterial atherosclerotic wall. Atherosclerosis 1996; 127: 263-271.

9. De Gennaro L, Brunetti ND, Montrone D, De Rosa F, Cuculo A, Di Biase M. Subacute inflammatory activation in subjects with acute coronary syndrome and left ventricular dysfunction. Inflammation 2012; 35: 363-370.

10. Mazzone A, De SS, Vezzoli M, Fossati G, Mazzucchelli I, Gritti D, Ottini E, Mus sini A, Specchia G. Plasma levels of interleukin 2, 6, 10 and phenotypic characterization of circulating $T$ lymphocytes in ischemic heart disease. Atherosclerosis 199; 145: 369-374

11. Negwera MN, Georgiev SJ, Penev AP. Cytokine interleukin-6 in patients with paroxysmal atrial fibrillation. Int J Pharm Med Res 2015; 3: 16-20.

12. Rong LQ, Kamel MK, Rahouma M, Naik A, Mehta K, Abouarab AA, Di Franco A, Demetres M, Mustapich TL, Fitzgerald MM, Pryor KO, Gaudino M. High-dose versus low-dose opioid anesthesia in adult cardiac surgery: a meta-analysis. J Clin Anesth 2019; 57: 57-62.

13. Luggya TS, Roche T, Ssemogerere L, Kintu A, Kasumba JM, Kwizera A, Tindimwebwa JV. Effect of low-dose ketamine on post-operative serum IL-6 production among elective surgical patients: a randomized clinical trial. Afr Health Sci 2017; 17: 500-507.

14. Li B, Li Y, Tian S, Wang H, Wu H, Zhang A, Gao C. Anti-inflammatory effects of perioperative dexmedetomidine administered as an adjunct to general anesthesia: a meta-analysis. Sci Rep 2015; 5: 123-142.

15. Oliveira de CMB, Sakata RK, Slullitel A, Salomão R, Lanchote VL, Issy AM. Effect of intraoperative intravenous lidocaine on pain and plasma interleukin- 6 in patients undergoing hysterectomy. Rev Bras Anestesiol 2015; 65: 92-98.

16. Yang S, Zheng R, Hu S, Ma Y, Choudhry MA, Messina JL, Rue LW $3^{\text {rd }}$, Bland KI, Chaudry $\mathrm{IH}$. Mechanism of cardiac depression after trauma-hemorrhage: increased cardiomyocyte IL- 6 and effect of sex steroids on IL- 6 regulation and cardiac function. Am J Physiol Heart Circ Physiol 2004; 287: H2183-H2191.

17. Sheu SS, Lederer WJ. Lidocaine's negative inotropic and antiarrhythmic actions. Dependence on shortening of action potential duration and reduction of intracellular sodium activity. Circ Res 1985; 57: 578-590.

18. Hayashi Y, Sumikawa K, Maze M, Yamatodani A, Kamibayashi T, Kuro M, Yoshiya I. Dexmedetomidine prevents epinephrine-induced arrhythmias through stimulation of central alpha 2 adrenoceptors in halothane-anesthetized dogs. Anesthesiology 1991; 75: 113-117.

19. Kamibayashi T, Hayashi Y, Mammoto T, Yamatodani A, Sumikawa K, Yoshiya I. Role of the vagus nerve in the antidysrhythmic effect of dexmedetomidine on halothane/epinephrine dysrhythmias in dogs. Anesthesiology 1995; 83 . 992-999.

20. Duncan D, Sankar A, Beattie WS, Wijeysundera DN. Alpha-2 adrenergic agonists for the prevention of cardiac complications among adults undergoing surgery. Cochrane Database Syst Rev 2018; 3: CD004126.

21. Guinot P, Spitz A, Berthoud V, Ellouze O, Missaoui A, Constandache T, Gros jean S, Radhouani M, Anciaux JB, Parthiot JP, Merle JP, Nowobilski N, Nguyen M, Bouhemad B. Effect of opioid-free anaesthesia on post-operative period in cardiac surgery: a retrospective matched case-control study. BMC Anesthesiol 2019; 19: 136

22. Peltoniemi MA, Hagelberg NM, Olkkola KT, Saari TI. Ketamine: a review of clinical pharmacokinetics and pharmacodynamics in anesthesia and pain therapy. Clin Pharmacokinet 2016; 55: 1059-1077. 